\title{
Pemanfaatan Tanaman Tithonia Diversifolia, Rumput Vetiveria Zizanioides dan Rumput Brachiaria Humidicola Sebagai Tanaman Penguat Teras dalam Pengendalian Erosi pada Kebun Kurma Lembah Barbatee, Blang Bintang Aceh Besar
}

\section{(Utilization Of Tithonia diversifolia, Vetiveria zizanioides and Brachiaria humidicola as A Terrace Reinforcement Plant for Erosion Control in Lembah Barbatee's Date Garden, Blang Bintang Aceh Besar)}

\author{
Maisurah Fadya ${ }^{1}$, Khairullah ${ }^{1}$, Yadi Jufri ${ }^{{ }^{*}}$ \\ ${ }^{1}$ Program Studi Ilmu Tanah, Fakultas Pertanian, Universitas Syiah Kuala \\ *Corresponding author: yadijufri@unsyiah.ac.id
}

\begin{abstract}
Abstrak. Indonesia merupakan negara tropis dengan curah hujan yang tinggi menjadi faktor utama penyebab terjadinya kerusakan tanah. Kerusakan tanah menyebabkan berkurangnya kemampuan tanah untuk menyerap dan menahan air serta terjadi sedimentasi pada tempat-tempat penampungan air seperti waduk, sungai, danau, saluran irigasi dan areal pertanian. Salah satu metode yang dapat digunakan dalam mengendalikan erosi yaitu metode vegetatif dengan memanfaatkan tanaman titonia (Tithonia diversifolia), rumput vetiver (Vetiveria zizanioides) dan rumput brachiaria (Brachiaria humidicola). Penelitian ini bertujuan untuk mengetahui kemampuan tanaman titonia, rumput vetiver dan rumput brachiaria dalam mengendalikan erosi pada lahan yang berlereng. Penelitian ini dilakukan di Kebun Kurma Lembah Barbatee, Blang Bintang Aceh Besar dengan membudidayakan/ menumbuhkan tanaman titonia pada lahan berlereng menggunakan plot pengamatan erosi. Hasil penelitian menunjukkan bahwa rumput vetiver mampu mengendalikan erosi dalam waktu 1 bulan, disebabkan oleh jarak tanamnya yang rapat dan populasi tanamannya banyak. Sementara tanaman titonia dapat mengurangi jumlah tanah yang tererosi setelah tanaman berumur 2 bulan dilapangan.
\end{abstract}

Kata Kunci : Erosi, tanaman titonia, rumput vetiver, rumput brachiaria, lahan berlereng.

\begin{abstract}
Indonesia is a tropical country of high rainfall. It is a major factoe in the deterioration of the soil. Soil damage causes the soil to be unable to absorb water, hold water, and can cause soil sedimentation in areas such as reservoirs, rivers, lakes, irrigation and agricultural areas. The vegetation method was one of the methods used to control erosion by tithonia (Tithonia diversifolia), vetiver grass (Vetiveria zizanioides) and brachiaria grass (Brachiaria humidicola). The main aim of this research to determine the ability of titonia to control the erosion on sloping land. This research was done in the Lembah Barbatee's date garden, Blang Bintang Aceh Besar by planting tithonia, vetiver grass and brachiaria grass on sloping land and using the erosion plots. The result of this was that vetiver grass was able to control erosion in 1 month due to spacing of dense plants and it has a large population. Tithonia was able to control erosion after being planted for 2 months.
\end{abstract}

Keywords : Erosion, tithonia, vetiver grass, brachiaria grass, sloping land

\section{PENDAHULUAN}

Erosi tanah merupakan suatu peristiwa hilang atau terkikisnya lapisan permukaan tanah (top soil) yang ditimbulkan oleh gerakan air atau angin pada permukaan tanah. Lapisan permukaan tersebut mengandung hara yang sangat penting bagi pertumbuhan tanaman. Tanah 
yang tererosi akan terangkut oleh aliran permukaan yang kemudian akan mengendap ditempat-tempat yang lebih rendah (Arnita, 2012).

Untuk mengurangi dampak dari terjadinya erosi, beberapa tahapan yang dapat di lakukan yaitu pengendalian secara mekanik, kimia dan vegetasi. Pengendalian secara vegetasi adalah pemanfaatan tanaman sebagai penutup tanah untuk menghindari air hujan langsung jatuh ke tanah. Cara vegetatif atau memanfaatkan tanaman dalam pengendalian erosi meliputi kegiatan seperti penghutanan kembali dan penghijauan, penanam tanaman penutup tanah, penanaman tanaman secara garis kontur, penanaman tanaman dalam strip, penanaman tanaman secara bergilir dan pemulsaan atau pemanfaatan serasah tanaman (Kartasapoetra dan Mul, 2010).

Tanaman yang sesuai untuk digunakan sebagai tanaman penutup tanah harus memenuhi beberapa syarat seperti mudah diperbanyak, memiliki sistem perakaran yang dalam dan tidak menimbulkan kompetisi berat bagi tanaman pokok tetapi memiliki sifat pengikat tanah yang baik dan tidak membutuhkan kesuburan tanah yang tinggi, tumbuh cepat, menghasilkan banyak daun, dan toleransi terhadap pemangkasan. Berdasarkan kriteria inilah, pada penelitian ini digunakan tiga jenis vegetasi yaitu tanaman titonia, rumput vetiver dan rumput brachiaria yang bertujuan untuk melihat kemampuan dari ketiga jenis vegetasi ini dalam pengendalian erosi pada lahan miring di kebun kurma Lembah Barbatee.

\section{METODE PENELITIAN}

Penelitian ini dilakukan di kebun Kurma Lembah Barbatee, Blangbintang, Aceh Besar. Penelitian ini dilakukan dengan membudidayakan/menumbuhkan tanaman titonia, rumput vetiver dan rumput braciaria dilahan miring dengan menggunakan plot pengamatan erosi yang berukuran $150 \mathrm{~cm}$ x $150 \mathrm{~cm} \times 30 \mathrm{~cm}$. Pengukuran jumlah tanah tererosi dilakukan setelah hujan dengan menghitung jumlah tanah yang tertampung didalam wadah penampung sedimentasi yang ditempatnya diluar plot pengamatan. Analisis tanah dilakukan di Laboratorium Penelitian Tanah dan Tanaman Universitas Syiah Kuala dan Laboratorium Fisika Tanah dan Lingkungan Universitas Syiah Kuala.

Penelitian ini menggunakan metode eksperimen yang didasarkan pada pengamatan pengaruh penggunaan vegetasi dalam pengendalian erosi. Penelitian ini menggunakan Rancangan Acak Kelompok (RAK) non Faktorial. Data pada penelitian ini terdiri dari 3 macam penutup tanah dengan 3 kali pengulangan, maka terdapat 12 plot pengamatan.

\section{Pelaksaan Penelitian}

Penelitian diawali dengan melakukan analisis tanah pada lahan yang dicobakan sebelum penanaman. Analisis tanah yang dilakukan yaitu Permeabiltas dan Stabilitas Agregat tanah. Selanjutnya tanaman titonia, rumput vetiver dan rumput brachiaria di pindahkan ke dalam plot dan ditanam dengan jarak tanam yang berbeda berdasarkan jenisnya. Tanaman titonia di tanaman dengan jarak tanam $50 \times 50 \mathrm{~cm}$, rumput vetiver $20 \times 20 \mathrm{~cm}$ dan rumput brachiaria $30 \times 30 \mathrm{~cm}$.

Untuk menampung air dan tanah yang tererosi, pada plot dibuat tiga lubang dengan ukuran yang sama. Salah satu lubang tersebut kemudian disambungkan dengan selang yang terhubung ke tempat penampungan sedimentasi yang ditempatkan dibawahnya plot. Air tanah yang tertampung di plot tersebut akan dianalisis di laboratorium. Pengukuran jumlah tanah 
tererosi dilakukan setelah 1 bulan penanaman. Pengukuran curah hujan dilakukan bersamaan saat pengukuran tanah tererosi. Analisis tanah dilakukan kembali setelah penanaman atau setelah tanaman berumur 3 bulan.

Hasil yang diperoleh dari pengamatan, dianalisis untuk melihat pengaruh pada variasi perlakuan dengan intensitas hujan terhadap erosi. Sebelum dilakukan analisis sidik ragam, data yang diperoleh ditranformasi menggunakan transformasi logaritma (Log Y).

\section{HASIL DAN PEMBAHASAN}

Pengukuran curah hujan dilakukan dengan menggunakan wadah air dan corong. Hasil pengukuran curah hujan yaitu sebagai berikut.

Tabel 1. Hasil Pengukuran Curah Hujan

\begin{tabular}{ccc}
\hline Pengamatan & $\begin{array}{c}\text { Curah Hujan } \\
(\mathrm{mm} / \text { hari })\end{array}$ & Kriteria \\
\hline 1 & 44,66 & Sedang \\
2 & 99,07 & Lebat \\
3 & 44,02 & Sedang \\
4 & 46,00 & Sedang \\
5 & 70,77 & Lebat \\
6 & 25,97 & Sedang \\
7 & 82,09 & Lebat \\
\hline
\end{tabular}

Berdasarkan Tabel 1, diketahui bahwa curah hujan yang terjadi bervariasi selama 2 bulan pengataman yaitu sejak bulan November sampai Desember. Tinggi rendah nya curah hujan sangat mempengaruhi jumlah limpasan air.

\section{Analisis Sifat Fisika Tanah}

Analisis sifat fisika tanah dilakukan sebanyak 2 kali, yaitu sebelum penanaman dan setelah 2 bulan pengamatan dilapangan. Adapun analisis yang telah dilakukan yaitu indeks stabilitas agregat dan permeabilitas tanah. Berikut hasil analisis sebelum dilakukan penanaman :

Tabel 2. Hasil Analisis Sebelum Tanam

\begin{tabular}{cccc}
\hline No. & Parameter & Nilai & Kriteria \\
\hline 1 & Permeabilitas & 9,37 & Agak cepat \\
2 & Indeks stabilitas agregat & 35,81 & Kurang Mantap \\
\hline
\end{tabular}


Hasil analisis awal menunjukkan bahwa tanah di kebun kurma Lembah Barbatee memiliki permeabilitas yang berada pada kelas agak cepat. Hal ini disebabkan karena tanah di lapangan banyak mengandung pasir sehingga memiliki pori-pori yang lebih besar dan mudah melewatkan air ke dalam tanah. Tanah yang bertektur pasir memiliki kemantapan agregat yang tidak stabil sehingga pada hasil analisis awal menunjukkan bahwa indeks kemantapan agregat tanah di kebun kurma Lembah Barbatee termasuk pada kelas tidak mantap.

Tabel 3. Hasil Analisis Setelah Tanam

\begin{tabular}{ccccc}
\hline Perlakuan & Permeabilitas & Kriteria & $\begin{array}{c}\text { Indeks Stabilitas } \\
\text { Agregat }\end{array}$ & Kriteria \\
\hline K1 & 1,28 & Agak Lambat & 49,85 & Kurang Mantap \\
K2 & 1,29 & Agak Lambat & 50,42 & Agak Mantap \\
K3 & 1,31 & Agak Lambat & 52,10 & Agak Mantap \\
T1 & 1,40 & Agak Lambat & 53,57 & Agak Mantap \\
T2 & 1,25 & Agak Lambat & 49,94 & Kurang Mantap \\
T3 & 1,37 & Agak Lambat & 52,82 & Agak Mantap \\
B1 & 1,38 & Agak Lambat & 52,25 & Agak Mantap \\
B2 & 1,41 & Agak Lambat & 53,45 & Agak Mantap \\
B3 & 1,35 & Agak Lambat & 52,12 & Agak Mantap \\
V1 & 1,34 & Agak Lambat & 52,54 & Agak Mantap \\
V2 & 1,37 & Agak Lambat & 52,47 & Agak Mantap \\
V3 & 1,35 & Agak Lambat & 52,14 & Agak Mantap \\
\hline
\end{tabular}

Keterangan :

- $\quad \mathrm{K}=$ kontrol

- $\quad \mathrm{T}=$ titonia

- $\quad \mathrm{B}=$ brachiaria

- $\quad \mathrm{V}=$ vetiver

Hal ini berbeda dengan hasil analisis setelah penanaman ketiga tanaman yang dicobakan. Hasil analisis sifat fisika tanah menunjukkan bahwa, indeks stabilitas agregrat tanah dari setiap perlakuan berada pada kelas agak mantap. Namun, hasil permeabilitas tanah pada setiap perlakuan berada pada kelas agak lambat. Hal ini disebabkan oleh dispersi tanah yang terjadi pada saat permukaan tanah belum tertutup sempurna, sehingga saat terjadi hujan partikel-partikel halus masuk ke dalam pori-pori tanah yang menyebabkan ruang pori-pori tanah menjadi kecil. 


\section{Hasil Pengamatan Erosi Tanah}

Pengamatan di lapangan dilakukan setelah tanaman berumur 2 bulan. Data yang diperoleh merupakan hasil kering oven yang telah dikalikan tiga berdasarkan jumlah lubang pada plot pengamatan. Berikut hasil pengamatan yang diperoleh:

Tabel 4. Rata-rata Hasil Pengukuran Tanah Tererosi

\begin{tabular}{cccccccc}
\hline \multirow{2}{*}{ Perlakuan } & \multicolumn{7}{c}{ Pengukuran (g/liter) } \\
\cline { 2 - 7 } & I & II & III & IV & V & VI & VII \\
\hline Kontrol & 562,7 & $1.401,40$ & 450,3 & 1.023 & 500,1 & 267,3 & 610,6 \\
Titonia & 155,8 & 586,9 & 70,8 & 78,15 & 2,1 & 5,25 & 30,2 \\
Brachiaria & 126,8 & 530,7 & 171,6 & 292,4 & 60,3 & 18,6 & 69,6 \\
Vetiver & 35,3 & 17,1 & 110,3 & 315,5 & 6,5 & 3,8 & 4,9 \\
\hline
\end{tabular}

Sumber : Hasil Analisis Pengukuran Lapangan

Pengukuran jumlah tanah yang tererosi dilakukan 1 bulan setelah tanam. Berdasarkan Tabel 7, pada pengukuran pertama erosi tanah tertinggi yaitu pada plot tanpa vegetasi (plot kontrol). Sementara erosi tanah terendah yaitu pada plot dengan perlakuan rumput vetiver. Masruroh (2013) mengatakan bahwa rumput vetiver memiliki batang yang kaku dan tumbuh tegak, bila ditanam berdekatan bahkan pada lahan miring akan membentuk seperti pagar yang mampu mengurangi limpasan permukaan.

Hasil pengukuran ke dua di lapangan dengan curah hujan tertinggi selama 2 bulan pengamatan. Hujan lebat yang terjadi menyebabkan kerusakan pada 3 plot pengamatan yaitu, plot titonia ulangan I, plot brachiaria ulangan I dan plot kontrol ulangan III. Kerusakan yang terjadi menyebabkan tanah yang tererosi tidak dapat diukur sampai hujan berakhir dikarenakan aliran permukaan tidak masuk ke dalam wadah penampung. Hasil yang diperoleh masih sama seperti pengamatan pertama yaitu erosi tanah terendah pada plot dengan rumput vetiver.

Kerusakan plot yang terjadi pada pengukuran ke dua tidak dapat diperbaiki, sehingga data pada plot yang rusak tidak dapat diamati. Pada pengukuran ke tiga yaitu pada minggu ke enam setelah tanam, tanaman titonia mulai tumbuh lebat menutupi permukaan tanah dengan baik. Berdasarkan Tabel 4, jumlah erosi tanah paling rendah pada pengkuruan ke tiga yaitu pada plot dengan perlakuan titonia. Hasil pengukuran ke empat, erosi terendah juga terjadi pada plot dengan tanaman titonia yang mulai tumbuh sedikit lebih lebat dari sebelumnya. Jarak waktu pengukuran ke tiga dan keempat hanya satu minggu.

Pertumbuhan tanaman titonia jauh lebih baik pada pengukuran ke lima, yaitu 2 bulan setelah tanam. Dibandingkan dengan tanaman lainnya, rumput brachiaria belum menutupi permukaan tanah dengan baik. Pengukuran ke enam berjarak 1 minggu dengan pengukuran ke lima memiliki curah hujan terendah selama 2 bulan pengamatan. Berdasarkan Tabel 4, ratarata tanah tererosi paling rendah yaitu pada perlakuan vetiver. Sama hal nya dengan pengukuran ke tujuh, erosi paling sedikit juga pada perlakuan vetiver. 


\section{Pengaruh Umur Tanaman}

Pengamatan hasil tanah tererosi dilakukan setelah tanaman berumur 1 sampai 3 bulan di lapangan. Perbedaan intensitas hujan dan pertumbuhan tanaman sangat mempengaruhi jumlah tanah yang tererosi. Pertumbuhan tanaman yang lambat, menyebabkan permukaan tanah tidak tertutup sempurna sehingga tanah lebih banyak tertampung dalam penampungan hasil sedimentasi saat terjadi hujan.

Tabel 5. Hasil Pengukuran Erosi 1 Bulan setelah Tanam

\begin{tabular}{|c|c|c|c|c|}
\hline \multirow{2}{*}{ Perlakuan } & \multicolumn{3}{|c|}{ Ulangan } & \multirow{2}{*}{ Jumlah } \\
\hline & I & II & III & \\
\hline Kontrol & 2,19 & 3,12 & 3,29 & 8,60 \\
\hline Titonia & 2,03 & 1,61 & 2,47 & 6,11 \\
\hline Brachiaria & 2,47 & 2,21 & 2,55 & 7,23 \\
\hline Vetiver & 0,23 & 1,03 & 2,17 & 3,44 \\
\hline Total & 6,93 & 7,97 & 10,48 & 25,38 \\
\hline
\end{tabular}

Berbedasarkan Tabel 5, jumlah erosi yang paling sedikit yaitu pada plot dengan perlakuan rumput vetiver. Satu minggu setelah dipindahkan dari polybag, pertumbuhan vetiver sangat baik. Jumlah populasi vetiver lebih banyak dibandingkan dengan tanaman lainnya, sehingga vetiver lebih mampu menahan laju erosi di awal penanaman.

Tabel 6. Hasil Pengukuran Erosi 2 Bulan setelah Tanam

\begin{tabular}{ccccc}
\hline \multirow{2}{*}{ Perlakuan } & I & Ulangan & \multirow{2}{*}{ III } & Jumlah \\
\hline Kontrol & 2,30 & 2,73 & 2,49 & 7,51 \\
Titonia & 0,72 & 0,24 & 0,85 & 1,81 \\
Brachiaria & 2,52 & 1,35 & 1,55 & 5,42 \\
Vetiver & 0,28 & 0,83 & 0,95 & 2,06 \\
\hline Total & 5,82 & 5,14 & 5,83 & 16,79 \\
\hline
\end{tabular}

Titonia mulai dapat menutupi permukaan dengan baik setelah 2 bulan penanaman. Seperti pendapat Hakim dan Agustian (2012), kanopi tanaman titonia tumbuh setelah 2 bulan dengan tinggi tanaman mencapai $99 \mathrm{~cm}$. Air hujan yang jatuh tidak langsung mengenai tanah melainkan tertahan oleh kanopi tanaman yang rapat sehingga melindungi permukaan tanah.

Tabel 7. Hasil Pengukuran erosi 3 Bulan setelah Tanam

\begin{tabular}{ccccc}
\hline \multirow{2}{*}{ Perlakuan } & \multicolumn{3}{c}{ Ulangan } & \multirow{2}{*}{ Jumlah } \\
\cline { 2 - 4 } & I & II & III & \\
\hline Kontrol & 2,45 & 2,97 & 2,52 & 7,94 \\
Titonia & 1,91 & 0,53 & 1,76 & 4,20 \\
Brachiaria & 3,12 & 1,97 & 1,66 & 6,75 \\
Vetiver & 0,11 & 1,03 & 0,76 & 1,90 \\
\hline Total & 7,59 & 6,50 & 6,70 & 20,79 \\
\hline
\end{tabular}

Pengamatan terakhir yaitu 3 bulan setelah tanam, semua vegetasi sudah tumbuh jauh lebih baik menutupi permukaan tanah. Jumlah sedimentasi terkecil pada pengukuran terakhir 
yaitu pada perlakuan rumput vetiver. Pertumbuhan tanaman yang sangat berpengaruh terhadap pengendalian erosi yaitu tanaman yang sangat baik menutupi permukaan tanah dengan sempurna sehingga dapat menghambat air hujan yang jatuh langsung mengenai permukaan tanah.

\section{KESIMPULAN DAN SARAN}

Dari hasil penelitian yang telah dilakukan menunjukkan bahwa rumput vetiver dapat mengendalikan erosi pada umur 1 bulan setelah tanaman, kemudian disusul oleh tanaman titonia yang dapat mengendalikan erosi pada umur 2 bulan setelah tanam. Selanjutnya, setelah 3 bulan penanaman, Brachiaria sudah tumbuh lebih baik menutupi permukaan tanah, sehingga Brachiaria mampu mengendalikan erosi pada umur 3 bulan setelah tanam. Adapun upaya yang dapat dilakukan untuk mengendalikan erosi pada kebun kurma Lembah Barbatee yaitu dengan menanami rumput vetiver sebagai tanaman penguat.

\section{DAFTAR PUSTAKA}

Arnita, R. 2012. Kajian pengaruh kerapatan tanaman terhadap erosi pada lahan yang ditanami rumput gajah (Pennisetum purpureum). Skripsi. Fakultas Teknik Universitas Syiah Kuala, Banda Aceh

Hakim, N., dan Agustian. 2012. Titonia untuk Pertanian Berkelanjutan. Andalas University Press, Padang.

Huntojungo, I., J.M, Supit., J. Husain., R.I, Kawulusan. 2013. Erosi dan Infiltrasi pada Lahan Hortikultura Berlereng di Kelurahan Rurukan. Universitas Sam Ratulangi, Manado.

Kartosapoetra, A.G., dan M.M, Sutedjo. 2010. Teknologi Konservasi Tanah dan Air. PT. Rineka Cipta, Jakarta.

Masruroh, I. 2013. Peran Rumput Vetiver dalam Mengurangi Laju Erosi. Universitas Negeri Malang, Malang. 